\title{
Reclassification of Paenibacillus ginsengisoli as a later heterotypic synonym of Paenibacillus
} anaericanus

\author{
Kwang Kyu Kim, Keun Chul Lee and Jung-Sook Lee
}

Correspondence

Jung-Sook Lee

jslee@kribb.re.kr
Korean Collection for Type Cultures, Biological Resource Center, Korea Research Institute of Bioscience and Biotechnology, 52 Eoeun-dong, Yuseong-gu, Daejeon 305-806, Republic of Korea
The genus Paenibacillus, type genus of the family Paenibacillaceae (De Vos et al., 2010), accommodates facultatively anaerobic or strictly aerobic, rod-shaped bacteria that have ellipsoidal spores in swollen sporangia, anteiso- $\mathrm{C}_{15: 0}$ as the major fatty acid and DNA G+C contents ranging from 36 to 59 mol\% (Ash et al., 1993; Shida et al., 1997; De Vos et al., 2009). Paenibacilli are ubiquitous in nature, especially in soil. At the time of writing, the genus Paenibacillus comprises 114 recognized species, of which nearly 70 have been isolated from soil environments including humus, phyllosphere, rhizosphere, soil and sediments (Daane et al., 2002; Euzéby, 2010). The genus Paenibacillus has remained monophyletic with ever-increasing numbers of species, but some tightly clustered taxa share $>99.5 \%$ 16S rRNA gene sequence similarity, e.g. Paenibacillus favisporus (Velázquez et al., 2004) and Paenibacillus cineris (Logan et al., 2004), Paenibacillus massiliensis (Roux \& Raoult, 2004) and Paenibacillus panacisoli (Ten et al., 2006), and Paenibacillus anaericanus (Horn et al., 2005) and Paenibacillus ginsengisoli (Lee et al., 2007b), which has led to taxonomic re-evaluation.

\footnotetext{
The GenBank/EMBL/DDBJ accession numbers for the 16S rRNA gene sequences of $P$. ginsengisoli KCTC $13931^{\top}$ and $L M G 23406^{\top}$ and $P$. anaericanus DSM $15890^{\top}$ and LMG $23658^{\top}$ are FN673695, FR690143, FN673694 and FR690142, respectively. The GenBank accession numbers for the rpoB gene sequences of $P$. ginsengisoli KCTC $13931^{\top}$ and $P$. anaericanus DSM $15890^{\top}$ are FN673684 and FN673683, respectively.
}

A supplementary table and figure are available with the online version of this paper.
P. ginsengisoli was described by Lee et al. (2007a) for a novel strain isolated from soil of a ginseng field, and its name was validated on Validation List no. 116 (Lee et al., 2007b). According to the original description, whilst $P$. ginsengisoli formed a tight phylogenetic clade with $P$. anaericanus due to the high $16 \mathrm{~S}$ rRNA gene sequence similarity between them, a DNA-DNA relatedness value of $62 \%$ and several phenotypic characteristics distinguished between the two species. However, the DNA-DNA relatedness value was just below the threshold for species delineation (Wayne et al., 1987) and resequencing of the $16 \mathrm{~S}$ rRNA genes of the type strains of $P$. anaericanus and $P$. ginsengisoli revealed that they share $99.9 \%$ sequence similarity, which raised the possibility of their relatedness at the species level. Subsequently, the taxonomic relationship between the two species was re-evaluated by examining a variety of genotypic and phenotypic criteria.

P. ginsengisoli KCTC $13931^{\mathrm{T}}\left(=\right.$ Gsoil $\left.1638^{\mathrm{T}}\right)$ and $P$. anaericanus DSM $15890^{\mathrm{T}}\left(=\mathrm{MH} 21^{\mathrm{T}}\right)$ were cultivated on tryptic soy agar (TSA) or broth (Difco) at $30{ }^{\circ} \mathrm{C}$ for $48 \mathrm{~h}$, unless stated otherwise. $P$. ginsengisoli LMG $23406^{\mathrm{T}}$ and $P$. anaericanus LMG $23658^{\mathrm{T}}$ were used for confirmation of $16 \mathrm{~S}$ rRNA gene sequences and phenotypic data. Genomic DNA was extracted by using an UltraClean microbial DNA isolation kit (MO BIO Laboratories).

The 16S rRNA gene was PCR-amplified using a universal bacterial primer set (27F and 1492R; Lane, 1991). The amplified PCR product was purified by using a PCR purification kit (Solgent) and sequenced directly by the fluorescent dye-terminator method using an ABI 3730XL Capillary DNA Analyzer (Applied Biosystems) at Solgent 
Co. Ltd (Daejeon, Korea). The full-length 16S rRNA gene sequence was compiled by using SeqMan software (DNASTAR) and aligned with published sequences retrieved from GenBank by using CLUSTAL_X (Thompson et al., 1997).

Almost-complete 16S rRNA gene sequences of $1475 \mathrm{nt}$, corresponding to Escherichia coli positions 28-1491 with gaps, were determined and compared with published sequences. The $16 \mathrm{~S}$ rRNA gene sequences of $P$. ginsengisoli (GenBank accession numbers FN673695, FR690143 and AB245382 for strains KCTC $13931^{\mathrm{T}}$, LMG $23406^{\mathrm{T}}$ and Gsoil $1638^{\mathrm{T}}$, respectively) showed $100 \%$ identity, but those of $P$. anaericanus (GenBank accession numbers FN673694 and AJ318909 for strains DSM $15890^{\mathrm{T}}$ and $\mathrm{MH} 21^{\mathrm{T}}$, respectively) shared only $99.7 \%$ similarity, which was due to five mismatches (four nucleotide substitutions and one gap). This discrepancy probably arose from a sequencing error by the original submitter, as the original sequence (GenBank accession no. AJ318909) contained two substitutions and one insertion in the highly conserved region of the 16S rRNA gene, and the 16S rRNA gene sequence of $P$. anaericanus LMG $23658^{\mathrm{T}}$ (GenBank accession no. FR690142) matched that of $P$. anaericanus DSM $15890^{\mathrm{T}}$ perfectly. Consequently, the 16S rRNA gene sequences of the type strains of $P$. ginsengisoli and P. anaericanus shared $99.9 \%$ similarity, showing only two nucleotide differences, which was slightly higher than reported previously (Lee et al., 2007a).

For the measurement of $\mathrm{G}+\mathrm{C}$ content, genomic DNA was extracted and purified by using a Blood \& Cell Culture DNA Midi kit (Qiagen). DNA was degraded enzymically into nucleosides, and $\mathrm{G}+\mathrm{C}$ content was determined by using reversed-phase HPLC, as described by Tamaoka \& Komagata (1984). DNA-DNA hybridization was carried out with photobiotin-labelled probes in microplate wells as described by Ezaki et al. (1989), using a Fluoroskan Ascent fluorescence plate reader (Thermo Life Science). The hybridization temperature was $42{ }^{\circ} \mathrm{C}$. Reciprocal experiments were performed with five replications per sample.

According to the results obtained by Lee et al. (2007a) and Horn et al. (2005), the DNA G+C contents of $P$. ginsengisoli Gsoil $1638^{\mathrm{T}}$ and P. anaericanus $\mathrm{MH} 21^{\mathrm{T}}$ were 50.7 and $42.6 \mathrm{~mol} \%$, respectively. However, the redetermined DNA $\mathrm{G}+\mathrm{C}$ contents of the type strains of $P$. ginsengisoli and $P$. anaericanus were $43.2 \pm 0.2$ and $42.2 \pm 0.1 \mathrm{~mol} \%$, respectively, which showed that the difference was less than the common range found within a species (Rosselló-Mora \& Amann, 2001). Besides, results of the DNA-DNA cross-hybridization between the type strains of $P$. ginsengisoli and $P$. anaericanus yielded a relatedness of $82.8 \%$ (reciprocal, $70.9 \%$ ), which was much higher than the value of $62 \%$ obtained by Lee et al. (2007a) and indicated that the two taxa constitute a single species (Wayne et al., 1987). These inconsistencies may possibly have been attributable to experimental errors by Lee et al. (2007a), i.e. poor-quality DNAs, due to impurities in DNA preparations or contamination of the culture with another organism, may have yielded misleading results, in that a comparative study for analysis of DNA G $+\mathrm{C}$ contents was not performed, the authenticity of the type strain of $P$. anaericanus was not confirmed and the type strain of $P$. anaericanus showed an unusual fatty acid profile in the previous study (Lee et al., 2007a). The apparent incongruity of the results from DNA-DNA hybridization has been reported in several recent studies dealing with taxonomic reclassification (Wang et al., 2008; Dobritsa et al., 2010; Chimetto et al., 2011).

To confirm the above results, we analysed the $r p o B$ gene, a single-copy gene encoding the $\beta$-subunit of RNA polymerase. It has already been reported that sequences of this protein-encoding gene have higher discriminatory power than 16S rRNA gene sequences, and sequence comparison of this gene has proven to be helpful to describe the relationships among closely related taxa (Drancourt et al., 2004; Durak et al., 2006; Adékambi et al., 2008; Hoshino et al., 2009). PCR-mediated amplification of the $r p o B$ gene and sequencing of the purified PCR product were carried out according to $\mathrm{Wu}$ et al. (2011) with some modifications: primers $1 \mathrm{~F}$ ( $5^{\prime}$-TTGRCAGGWCAACTWGTTCA-3') and 3384R (5'-GAAYGATTCCGGAACRCCTGGTTC- ${ }^{\prime}$ ), which were designed in this study, were used instead of primers $73 \mathrm{~F}$ and 3306R, respectively.

Almost-complete $r p o B$ gene sequences of $3343 \mathrm{nt}$, corresponding to positions 21-3359 of the Bacillus subtilis sequence (GenBank accession no. AL009126) with gaps, were determined. The $r p o B$ gene sequences of the type strains of $P$. ginsengisoli and $P$. anaericanus shared $99.6 \%$ similarity, which was clearly above the cut-off value for species delineation (97.7\%; Adékambi et al., 2008) and fell within the range of intraspecific $r p o B$ gene sequence similarity (98.2-100\%; Adékambi et al., 2008). Consequently, comparative sequence analysis of the $r p o B$ gene could complement the DNA-DNA hybridization data.

For analysis of fatty acids, cells were grown on TSA for 3 days at the optimal growth temperature $\left(30^{\circ} \mathrm{C}\right)$, as well as at $25{ }^{\circ} \mathrm{C}$ for comparison with the previous data obtained by Lee et al. (2007a). Fatty acid methyl esters were prepared and analysed as described by Klatte et al. (1994) by using the standard Microbial Identification System (MIDI) for automated GC analysis (Sasser, 1990; Kämpfer \& Kroppenstedt, 1996).

In contrast to data reported previously (Lee et al., 2007a), the type strains of $P$. ginsengisoli and $P$. anaericanus had very similar fatty acid profiles, i.e. the fatty acid anteiso- $\mathrm{C}_{15: 0}$ was predominant, and no significant quantitative or qualitative differences were detected in the fatty acid compositions, regardless of the conditions under which cells were grown. Members of the genus Paenibacillus have been described to contain anteiso- $\mathrm{C}_{15: 0}$ as the major fatty acid (Ash et al., 1993; Shida et al., 1997; De Vos et al., 2009). However, according to the data obtained by Lee et al. (2007a), the type 
strain of $P$. anaericanus had iso- $\mathrm{C}_{15: 0}$ as the major fatty acid, a finding that was not repeated in this study. Detailed fatty acid compositions are shown in Table 1 and Supplementary Table S1 (available in IJSEM Online).

The Gram reaction was performed as described by Smibert \& Krieg (1994) with cells grown at $30{ }^{\circ} \mathrm{C}$ for $24 \mathrm{~h}$. Cell morphology and motility were observed under a phasecontrast microscope (Eclipse 80i, Nikon; × 1000 magnification). For the observation of flagella, cells were negatively stained with $1 \%(\mathrm{w} / \mathrm{v})$ uranyl acetate and examined using a model $\mathrm{H}-7600$ transmission electron microscope (Hitachi). Oxidase activity was tested by using oxidase reagent (bioMérieux), and catalase activity was determined by production of bubbles after the addition of a drop of $3 \% \mathrm{H}_{2} \mathrm{O}_{2}$. Growth was investigated at 5, 10, 15, $20,25,30,35,37,40$ and $42{ }^{\circ} \mathrm{C}$ and in the presence of 1,2 , 3, 5 and $10 \%(\mathrm{w} / \mathrm{v}) \mathrm{NaCl}$. Hydrolysis of DNA, casein and starch was tested on DNase test agar, casein agar and starch agar (BBL), respectively. Hydrolysis of Tweens 20 and 80 was examined by using the method of Sierra (1957). Production of lecithinase was detected on egg yolk agar (McClung \& Toabe, 1947). $\mathrm{H}_{2} \mathrm{~S}$ production was tested in tryptic soy broth supplemented with $0.01 \%(\mathrm{w} / \mathrm{v})$ cysteine, with a strip of lead acetate paper (Fluka) as an indicator. The methyl red and Voges-Proskauer tests were performed in MR-VP broth (BBL). Single carbon-source assimilation tests were performed as described by Kim et al. (2010). Acidproduction tests, enzyme-activity tests and additional phenotypic tests were performed using API 50CH (with CHB/E medium), API ZYM, API 20E and API 20NE galleries according to the instructions of the manufacturer (bioMérieux). Antibiotic-susceptibility tests were performed using Sensi-Discs (6 mm; BBL) containing the following: amikacin $(30 \mu \mathrm{g})$, ampicillin $(10 \mu \mathrm{g})$, bacitracin (10 IU), ceftazidime $(30 \mu \mathrm{g})$, ceftriaxone $(30 \mu \mathrm{g})$, cephalothin $(30 \mu \mathrm{g})$, ciprofloxacin $(5 \mu \mathrm{g})$, colistin $(10 \mu \mathrm{g})$, doxycycline $(30 \mu \mathrm{g})$, gentamicin $(10 \mu \mathrm{g})$, imipenem $(10 \mu \mathrm{g})$, norfloxacin $(10 \mu \mathrm{g})$, novobiocin $(30 \mu \mathrm{g})$, oxacillin $(1 \mu \mathrm{g})$, polymyxin B (300 IU) and tobramycin $(10 \mu \mathrm{g})$.

Cells of the type strains of $P$. ginsengisoli and $P$. anaericanus were Gram-reaction-negative, catalase- and oxidase-positive, motile rods with peritrichous flagella (see Supplementary Fig. S1, available in IJSEM Online). The type strains of $P$. ginsengisoli and $P$. anaericanus showed identical antibiotic-susceptibility profiles: they were susceptible to amikacin, ampicillin, bacitracin, ceftazidime, ceftriaxone, cephalothin, ciprofloxacin, doxycycline, gentamicin, imipenem, norfloxacin, novobiocin, polymyxin B and tobramycin, but resistant to colistin and oxacillin. The physiological and biochemical characteristics of KCTC $13931^{\mathrm{T}}$ and DSM $15890^{\mathrm{T}}$ are listed in Table 2 . The strains shared almost-identical characteristics, except for $\beta$-glucosidase

Table 1. Cellular fatty acid composition (\%) of the type strains of $P$. ginsengisoli and $P$. anaericanus grown at $25{ }^{\circ} \mathrm{C}$

Fatty acids are listed using standard abbreviations (no. of carbon atoms: no. of double bonds). Means \pm SD are given where appropriate. ND, Not detected.

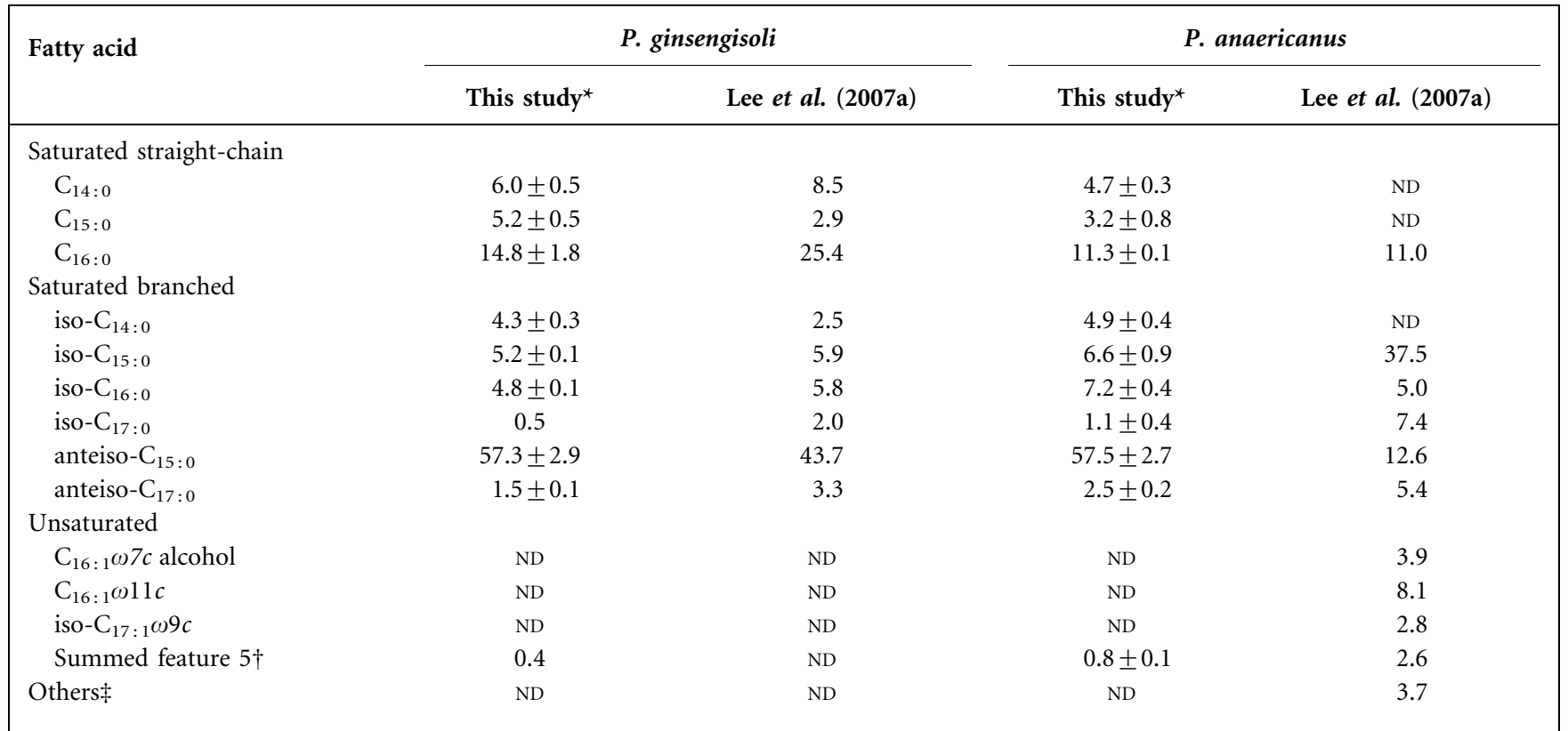

${ }^{*}$ Strains KCTC $13931^{\mathrm{T}}$ and LMG $23406^{\mathrm{T}}$ were used for P. ginsengisoli, and strains DSM $15890^{\mathrm{T}}$ and LMG $23658^{\mathrm{T}}$ for P. anaericanus. $\dagger$ Summed feature 5 comprises iso- $\mathrm{C}_{17: 1} \mathrm{I}$ and/or anteiso- $\mathrm{C}_{17: 1} \mathrm{~B}$, which could not be separated by the MIDI system.

$\$$ Not defined by Lee et al. (2007a). 
Table 2. Physiological and biochemical characteristics of the type strains of $P$. ginsengisoli and $P$. anaericanus

Strains: 1, P. ginsengisoli KCTC $13931^{\mathrm{T}}$; 2, P. anaericanus DSM $15890^{\mathrm{T}}$. Data were obtained in this study. + , Positive; $(+)$, weakly positive; - , negative. Both strains were positive for catalase, oxidase and motility; negative for arginine dihydrolase, lysine decarboxylase, ornithine decarboxylase, phenylalanine deaminase, urease and indole production; and showed identical profiles in terms of acid production from carbohydrates and antibiotic susceptibility.

\begin{tabular}{|c|c|c|}
\hline Characteristic & 1 & 2 \\
\hline Gram reaction & - & - \\
\hline $\begin{array}{l}\text { Temperature range } \\
\text { (optimum) for growth }\left({ }^{\circ} \mathrm{C}\right)\end{array}$ & $5-40^{*}(30-35)^{*}$ & $5-40(30-35)$ \\
\hline \multicolumn{3}{|l|}{ Growth with: } \\
\hline $3 \%(\mathrm{w} / \mathrm{v}) \mathrm{NaCl}$ & + & + \\
\hline $5 \%(\mathrm{w} / \mathrm{v}) \mathrm{NaCl}$ & $-{ }^{*}$ & - \\
\hline Methyl red test & - & - \\
\hline Voges-Proskauer test & + & $+\dagger$ \\
\hline $\mathrm{H}_{2} \mathrm{~S}$ production & - & - \\
\hline Nitrate reduction & + & $+\dagger$ \\
\hline$\beta$-Glucosidase $\neq$ & + & - \\
\hline Lecithinase on egg yolk agar & - & - \\
\hline \multicolumn{3}{|l|}{ Utilization of: } \\
\hline $\mathrm{N}$-Acetylglucosamine & $(+)^{*}$ & + \\
\hline D-Fructose & - & $(+)$ \\
\hline D-Ribose & $+^{*}$ & + \\
\hline D-Xylose & $+^{*}$ & + \\
\hline \multicolumn{3}{|l|}{ Hydrolysis of: } \\
\hline Aesculin & $+^{*}$ & + \\
\hline Casein & - & - \\
\hline DNA & - & - \\
\hline Gelatin & - & - \\
\hline Starch & $+^{*}$ & $(+)$ \\
\hline Tween 20 & - & - \\
\hline Tween 80 & - & - \\
\hline
\end{tabular}

${ }^{\star}$ Data not congruent with those reported by Lee et al. (2007a). $\dagger$ Data not congruent with those reported by Horn et al. (2005). $\ddagger$ Data from API ZYM tests.

activity and utilization of D-fructose. Strains LMG $23406^{\mathrm{T}}$ and LMG $23658^{\mathrm{T}}$ gave identical results to strains KCTC $13931^{\mathrm{T}}$ and DSM $15890^{\mathrm{T}}$, respectively, which confirmed that there were no significant characteristics differentiating between $P$. ginsengisoli and P. anaericanus.

On the basis of the genotypic and phenotypic evidence described above, the species $P$. ginsengisoli and $P$. anaericanus constitute a single genomic species, without differentiation at the subspecies level. Therefore, it is proposed that the two species be united under the same name. According to the rules of priority (Rules 38 and 42 of the Bacteriological Code; Lapage et al., 1992), the name Paenibacillus anaericanus should be retained for the united taxon, with Paenibacillus ginsengisoli as a later heterotypic synonym.

\section{Emended description of Paenibacillus anaericanus Horn et al. 2005}

The description is as given by Horn et al. (2005) with the following additions and modifications. Cells are motile by means of peritrichous flagella. Growth occurs in the presence of up to $3 \%(\mathrm{w} / \mathrm{v}) \mathrm{NaCl} . \mathrm{H}_{2} \mathrm{~S}$ is not produced. Nitrate is reduced. The methyl red test is negative, but the Voges-Proskauer test is positive. Aesculin is hydrolysed, but casein, DNA and Tweens 20 and 80 are not. Lecithinase and ornithine decarboxylase are not produced. On the basis of the method of Kim et al. (2010), amygdalin, L-arabinose, D-galactose, glycogen, melibiose, D-ribose, D-salicin, trehalose, turanose and D-xylose are utilized as sole sources of carbon and energy, but L-alanine, L-arabitol, L-fucose, gentiobiose, gluconate, glycerol, L-histidine, malate, malonate, D-mannitol, melezitose, L-proline, raffinose, L-rhamnose and L-serine are not. In the API $50 \mathrm{CH}$ gallery, acid is produced from $\mathrm{N}$-acetylglucosamine, aesculin, amygdalin, L-arabinose, arbutin, cellobiose, D-fructose, D-galactose, gentiobiose, D-glucose, glycerol, glycogen, inulin, lactose, maltose, $\mathrm{D}$-mannose, melibiose, methyl $\alpha$-D-glucoside, methyl $\beta$-Dxyloside, raffinose, L-rhamnose, D-ribose, D-salicin, starch, sucrose, trehalose, turanose and D-xylose, but not from D-adonitol, D-arabinose, D- or L-arabitol, dulcitol, erythritol, D- or L-fucose, gluconate, inositol, 2- or 5-ketogluconate, D-lyxose, D-mannitol, melezitose, methyl $\alpha$-D-mannoside, D-sorbitol, L-sorbose, D-tagatose, xylitol or L-xylose. According to the results of the API ZYM test, esterase (C4), esterase lipase (C8), leucine arylamidase and $\beta$-galactosidase are present, but alkaline phosphatase, lipase $(\mathrm{C} 14)$, valine arylamidase, cystine arylamidase, trypsin, $\alpha$-chymotrypsin, acid phosphatase, naphthol-AS-BI-phosphohydrolase, $\alpha$ galactosidase, $\beta$-glucuronidase, $\alpha$-glucosidase, $N$-acetyl- $\beta$ glucosaminidase, $\alpha$-mannosidase and $\alpha$-fucosidase are absent. Susceptible to amikacin, ampicillin, bacitracin, ceftazidime, ceftriaxone, cephalothin, ciprofloxacin, doxycycline, gentamicin, imipenem, norfloxacin, novobiocin, polymyxin B and tobramycin. Resistant to colistin and oxacillin. The major fatty acid is antesio- $\mathrm{C}_{15: 0}$. The $\mathrm{G}+\mathrm{C}$ content of the DNA is 42.2-43.2 $\mathrm{mol} \%$.

\section{Acknowledgements}

This work was supported by grants from the KRIBB Research Initiative Program and the Ministry of Education, Science and Technology (MEST) of the Republic of Korea (grant no. M10437010001).

\section{References}

Adékambi, T., Shinnick, T. M., Raoult, D. \& Drancourt, M. (2008). Complete $r p o B$ gene sequencing as a suitable supplement to DNADNA hybridization for bacterial species and genus delineation. Int $J$ Syst Evol Microbiol 58, 1807-1814.

Ash, C., Priest, F. G. \& Collins, M. D. (1993). Molecular identification of rRNA group 3 bacilli (Ash, Farrow, Wallbanks and Collins) using a PCR probe test. Proposal for the creation of a new genus Paenibacillus. Antonie van Leeuwenhoek 64, 253-260. 
Chimetto, L. A., Cleenwerck, I., Brocchi, M., Willems, A., De Vos, P. \& Thompson, F. L. (2011). Marinomonas brasilensis sp. nov., isolated from the coral Mussismilia hispida, and reclassification of Marinomonas basaltis as a later heterotypic synonym of Marinomonas communis. Int $J$ Syst Evol Microbiol 61, 1170-1175.

Daane, L. L., Harjono, I., Barns, S. M., Launen, L. A., Palleron, N. J. \& Häggblom, M. M. (2002). PAH-degradation by Paenibacillus spp. and description of Paenibacillus naphthalenovorans sp. nov., a naphthalene-degrading bacterium from the rhizosphere of salt marsh plants. Int J Syst Evol Microbiol 52, 131-139.

De Vos, P., Ludwig, W., Schleifer, K.-H. \& Whitman, W. B. (2009). Family IV. Paenibacillaceae fam. nov. In Bergey's Manual of Systematic Bacteriology, 2nd edn, vol. 3, p. 269. Edited by P. De Vos, G. M. Garrity, D. Jones, N. R. Krieg, W. Ludwig, F. A. Rainey, K. H. Schleifer \& W. B. Whitman. New York: Springer.

De Vos, P., Ludwig, W., Schleifer, K.-H. \& Whitman, W. B. (2010). Paenibacillaceae fam. nov. In List of New Names and New Combinations Previously Effectively, but not Validly, Published, Validation List no. 132. Int J Syst Evol Microbiol 60, 469-472.

Dobritsa, A. P., Reddy, M. C. S. \& Samadpour, M. (2010). Reclassification of Herbaspirillum putei as a later heterotypic synonym of Herbaspirillum huttiense, with the description of $H$. huttiense subsp. huttiense subsp. nov. and $H$. huttiense subsp. putei subsp. nov., comb. nov., and description of Herbaspirillum aquaticum sp. nov. Int J Syst Evol Microbiol 60, 1418-1426.

Drancourt, M., Roux, V., Fournier, P. E. \& Raoult, D. (2004). $r p o B$ gene sequence-based identification of aerobic Gram-positive cocci of the genera Streptococcus, Enterococcus, Gemella, Abiotrophia, and Granulicatella. J Clin Microbiol 42, 497-504.

Durak, M. Z., Fromm, H. I., Huck, J. R., Zadoks, R. N. \& Boor, K. J. (2006). Development of molecular typing methods for Bacillus spp. and Paenibacillus spp. isolated from fluid milk products. J Food Sci 71, 50-56.

Euzéby, J. P. (2010). List of Prokaryotic Names with Standing in Nomenclature. http://www.bacterio.cict.fr/

Ezaki, T., Hashimoto, Y. \& Yabuuchi, E. (1989). Fluorometric deoxyribonucleic acid-deoxyribonucleic acid hybridization in microdilution wells as an alternative to membrane filter hybridization in which radioisotopes are used to determine genetic relatedness among bacterial strains. Int J Syst Bacteriol 39, 224-229.

Horn, M. A., Ihssen, J., Matthies, C., Schramm, A., Acker, G. \& Drake, H. L. (2005). Dechloromonas denitrificans sp. nov., Flavobacterium denitrificans sp. nov., Paenibacillus anaericanus sp. nov. and Paenibacillus terrae strain $\mathrm{MH} 72, \mathrm{~N}_{2} \mathrm{O}$-producing bacteria isolated from the gut of the earthworm Aporrectodea caliginosa. Int J Syst Evol Microbiol 55, 1255-1265.

Hoshino, T., Nakabayashi, T., Hirota, K., Matsuno, T., Koiwa, R., Fujiu, S., Saito, I., Tkachenko, O. B., Matsuyama, H. \& Yumoto, I. (2009). Paenibacillus macquariensis subsp. defensor subsp. nov., isolated from boreal soil. Int J Syst Evol Microbiol 59, 20742079.

Kämpfer, P. \& Kroppenstedt, R. M. (1996). Numerical analysis of fatty acid patterns of coryneform bacteria and related taxa. Can $J$ Microbiol 42, 989-1005.

Kim, K. K., Lee, K. C., Yu, H., Ryoo, S., Park, Y. \& Lee, J.-S. (2010). Paenibacillus sputi sp. nov., isolated from the sputum of a patient with pulmonary disease. Int J Syst Evol Microbiol 60, 2371-2376.

Klatte, S., Rainey, F. A. \& Kroppenstedt, R. M. (1994). Transfer of Rhodococcus aichiensis Tsukamura 1982 and Nocardia amarae Lechevalier and Lechevalier 1974 to the genus Gordona as Gordona aichiensis comb. nov. and Gordona amarae comb. nov. Int J Syst Bacteriol 44, 769-773.
Lane, D. J. (1991). 16S/23S rRNA sequencing. In Nucleic Acid Techniques in Bacterial Systematics, pp. 115-175. Edited by E. Stackebrandt \& M. Goodfellow. Chichester, UK: Wiley.

Lapage, S. P., Sneath, P. H. A., Lessel, E. F., Skerman, V. B. D., Seelinger, H. P. R. \& Clark, W. A. (editors) (1992). International Code of Nomenclature of Bacteria (1990 Revision). Bacteriological Code. Washington, DC: American Society for Microbiology.

Lee, M., Ten, L. N., Baek, S.-H., Im, W.-T., Aslam, Z. \& Lee, S.-T. (2007a). Paenibacillus ginsengisoli sp. nov., a novel bacterium isolated from soil of a ginseng field in Pocheon Province, South Korea. Antonie van Leeuwenhoek 91, 127-135.

Lee, M., Ten, L. N., Baek, S.-H., Im, W.-T., Aslam, Z. \& Lee, S.-T. (2007b). Paenibacillus ginsengisoli sp. nov. In List of New Names and New Combinations Previously Effectively, but not Validly, Published, Validation List no. 116. Int J Syst Evol Microbiol 57, 1371-1373.

Logan, N. A., De Clerck, E., Lebbe, L., Verhelst, A., Goris, J., Forsyth, G., Rodríguez-Díaz, M., Heyndrickx, M. \& De Vos, P. (2004). Paenibacillus cineris sp. nov. and Paenibacillus cookii sp. nov., from Antarctic volcanic soils and a gelatin-processing plant. Int J Syst Evol Microbiol 54, 10711076.

McClung, L. S. \& Toabe, R. (1947). The egg yolk plate reaction for the resumptive diagnosis of Clostridium sporogenes and certain species of the gangrene and botulinum groups. J Bacteriol 53, 139-147.

Rosselló-Mora, R. \& Amann, R. (2001). The species concept for prokaryotes. FEMS Microbiol Rev 25, 39-67.

Roux, V. \& Raoult, D. (2004). Paenibacillus massiliensis sp. nov., Paenibacillus sanguinis sp. nov. and Paenibacillus timonensis sp. nov., isolated from blood cultures. Int J Syst Evol Microbiol 54, 1049-1054.

Sasser, M. (1990). Identification of bacteria by gas chromatography of cellular fatty acids. MIDI Technical Note 101. Newark, DE: MIDI, Inc.

Shida, O., Takagi, H., Kadowaki, K., Nakamura, L. K. \& Komagata, K. (1997). Transfer of Bacillus alginolyticus, Bacillus chondroitinus, Bacillus curdlanolyticus, Bacillus glucanolyticus, Bacillus kobensis, and Bacillus thiaminolyticus to the genus Paenibacillus and emended description of the genus Paenibacillus. Int J Syst Bacteriol 47, 289298.

Sierra, G. (1957). A simple method for the detection of lipolytic activity of micro-organisms and some observations on the influence of the contact between cells and fatty substrates. Antonie van Leeuwenhoek 23, 15-22.

Smibert, R. M. \& Krieg, N. R. (1994). General characterization. In Methods for General and Molecular Bacteriology, pp. 607-654. Edited by P. Gerhardt, R. G. E. Murray, W. A. Wood \& N. R. Krieg. Washington, DC: American Society for Microbiology.

Tamaoka, J. \& Komagata, K. (1984). Determination of DNA base composition by reversed-phase high-performance liquid chromatography. FEMS Microbiol Lett 25, 125-128.

Ten, L. N., Baek, S.-H., Im, W.-T., Lee, M., Oh, H. W. \& Lee, S.-T. (2006). Paenibacillus panacisoli sp. nov., a xylanolytic bacterium isolated from soil in a ginseng field in South Korea. Int J Syst Evol Microbiol 56, 2677-2681.

Thompson, J. D., Gibson, T. J., Plewniak, F., Jeanmougin, F. \& Higgins, D. G. (1997). The CLUSTAL_X windows interface: flexible strategies for multiple sequence alignment aided by quality analysis tools. Nucleic Acids Res 25, 4876-4882.

Velázquez, E., de Miguel, T., Poza, M., Rivas, R., Rosselló-Mora, R. \& Villa, T. G. (2004). Paenibacillus favisporus sp. nov., a xylanolytic bacterium isolated from cow faeces. Int J Syst Evol Microbiol 54, $59-64$. 
Wang, L. T., Lee, F. L., Tai, C. J. \& Kuo, H. P. (2008). Bacillus velezensis is a later heterotypic synonym of Bacillus amyloliquefaciens. Int J Syst Evol Microbiol 58, 671-675.

Wayne, L. G., Brenner, D. J., Colwell, R. R., Grimont, P. A. D., Kandler, O., Krichevsky, M. I., Moore, L. H., Moore, W. E. C., Murray, R. G. E. \& other authors (1987). International Committee on Systematic
Bacteriology. Report of the ad hoc committee on reconciliation of approaches to bacterial systematics. Int J Syst Bacteriol 37, 463464.

Wu, X., Fang, H., Qian, C., Wen, Y., Shen, X., Li, O. \& Gao, H. (2011). Paenibacillus tianmuensis sp. nov., isolated from soil. Int J Syst Evol Microbiol 61, 1133-1137. 